\title{
Tetraazamacrocyclic Ligands and their Zinc(II) Complexes: Synthesis, Characterization and Biological Activities
}

\section{Saswata Rabi ${ }^{1}$, Sabina Yasmin ${ }^{2}$, Foni Bushon Biswas ${ }^{2}$, Rahul Das ${ }^{2}$, Debashis Palit ${ }^{2}$ and Tapashi Ghosh Roy ${ }^{2 *}$}

${ }^{1}$ Department of Chemistry, Chittagong University of Engineering and Technology, Bangladesh

${ }^{2}$ Department of Chemistry, University of Chittagong, Bangladesh

*Corresponding Author: Tapashi Ghosh Roy, Department of Chemistry, University of Chittagong, Bangladesh.

DOI: 10.31080/ASPS.2020.04.0566
Received: June 27, 2020

Published: July 23, 2020

(C) All rights are reserved by Tapashi Ghosh

Roy., et al.

\begin{abstract}
The hexamethyl tetraazamacrocyclic ligand salt, $\mathrm{Me}_{6}[14]$ diene. $2 \mathrm{HClO}_{4}\left(\mathrm{~L} .2 \mathrm{HClO}_{4}\right)$ has been synthesized by the condensation of ethylenediamine with acetone in the presence of $\mathrm{HClO}_{4}$, then two isomeric ligands tet-a and tet-b have been isolated from its reduced form. These ligands produced bimetallic and monometallic nitratozinc(II) complexes with $\mathrm{Zn}\left(\mathrm{NO}_{3}\right)_{2} \cdot 6 \mathrm{H}_{2} \mathrm{O}$. The nitratozinc(II) complexes, $\left[(\mathrm{ZnL})_{2}\left(\mathrm{NO}_{3}\right)\right]\left(\mathrm{ClO}_{4}\right)_{3},\left[\mathrm{Zn}(\right.$ tet-a $\left.)\left(\mathrm{NO}_{3}\right)_{2}\right]$ and $\left[\mathrm{Zn}\left(\right.\right.$ tet-b) $\left.\left(\mathrm{NO}_{3}\right)_{2}\right]$ underwent axial addition and substitution reactions with $\mathrm{KX}$ $\left(\mathrm{X}=\mathrm{SCN}, \mathrm{NO}_{2}\right.$, I or $\mathrm{Br}$ ) in proper ratio to produce twelve new corresponding monometallic six coordinated octahedral complexes. The newly prepared complexes have been characterized on the basis of elemental analyses, IR, UV-Vis, and ${ }^{1} \mathrm{H}-\mathrm{NMR}$ spectroscopic, magnetic and molar conductivity data. Antibacterial activities of the ligands and complexes against different gram positive and gram negative bacteria have been investigated.
\end{abstract}

Keywords: Macrocyclic Ligands; Zinc(II) Complexes; Axial Addition and Substitution; Spectroscopic Studies; Antibacterial Activities

\section{Introduction}

The fondness for macrocycles over simple unidentate or bidentate ligands, in certain cases, has arisen from the greater stability and inertness of their complexes as well as the often extreme physical properties that are a result of their strong ligand field, especially in the case of the aza-macrocycles [1]. The synthesis and characterization of tetraaza-macrocyclic complexes have been found to act as possible models for biochemically important proteins and complexes like vitamin $\mathrm{B}_{12}$, myoglobin, hemoglobin, chlorophyll etc.) to provide us an easier approach to the study of fundamental properties of metal ions encapsulated in a macrocyclic environment $[2,3]$. Complexes of ligands related to cyclam (fourteen membered tetraazamacrocyclic ligands) have been explored for their use in crystal engineering [4], therapeutic reagents [5], chemical sensor, ion transporter, MRI contrast agents [6] and as catalysts [7]. Among these applications catalytic activity of these macrocyclic complexes has a major contribution to the green chemistry. Further, they appear very promising for potential use as antibacterial, antifungal [8], antioxidants [9], antiproliferative [10], antidiabetic [11] antitumor [12] and anticancer [13] drug. Different zinc(II) complexes with different macrocyclic ligands are available in the literature [14-17]. Similarly some studies on present hexamethyl substituted tetraazmacrocyclic diene ligand $\mathrm{L}$ and isomers (tet-a and tet-b) of its reduced form as well as some of their zinc(II) complexes are reported [18-21]. But axial addition and substitution complexes of the concerned ligands have not been reported so far. So it seems attracting to study whether axial addition and substitution reaction products on zinc(II) complexes of the con- 
cerned ligands could be prepared. Keeping this in mind, the ligand salt, hexamethyl tetraazacyclotetradecadiene dihydroperchlorate ( $\mathrm{L} .2 \mathrm{HClO}_{4}$ ) and two isomeric ligands, tet-a and tet-b of its reduced form were prepared [22,23] (Scheme 1) and nitratozinc(II) complexes of concerned ligands have also been prepared as per our report (Chart 1) [19]. Axial addition and substitution reactions on these complexes have been carried out to result twelve addition and substitution products. In this work we report synthesis, characterization and antibacterial activities of these new axial addition and substitution reaction products of nitratozinc(II) complexes of the concerned ligands.

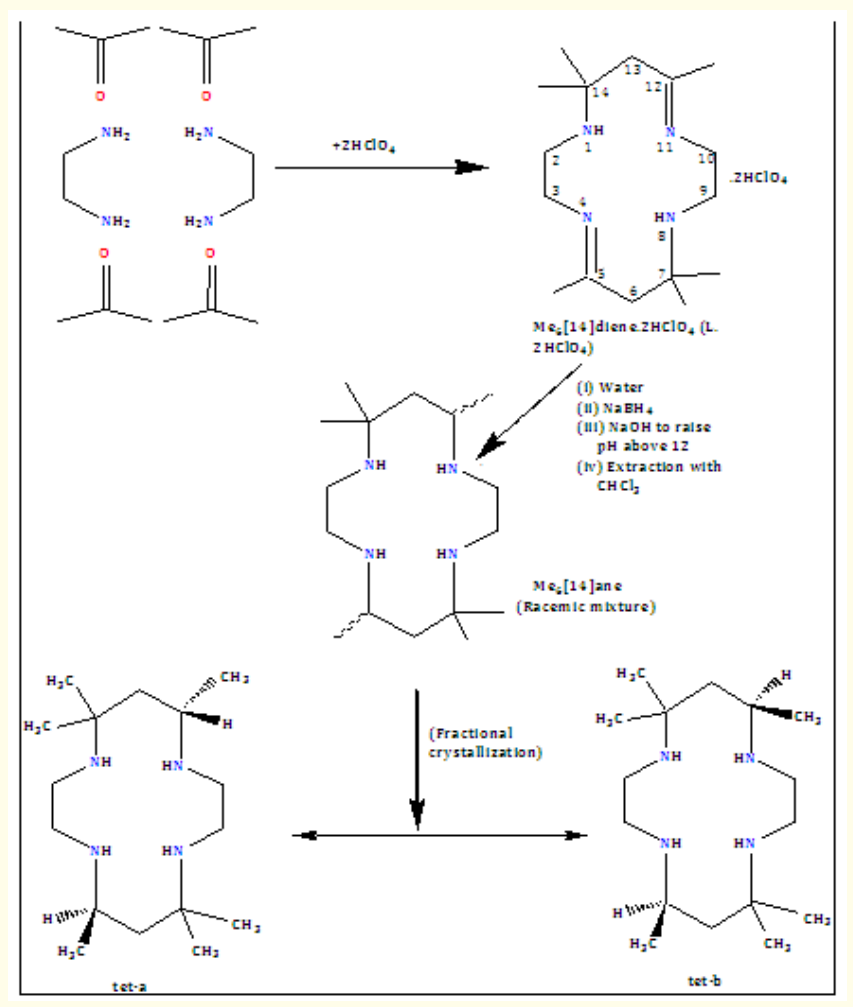

Scheme 1: Synthesis of a diene ligand salt L.2HClO4 and isomeric ligands tet-a and tet-b.

\section{Materials and Methods}

Ethylenediamine, $\mathrm{HClO}_{4}$, sodium borohydride (Merck, Germany), $\mathrm{Zn}\left(\mathrm{NO}_{3}\right)_{2} \cdot 6 \mathrm{H}_{2} \mathrm{O}$ and $\mathrm{KX}\left(\mathrm{X}=\mathrm{SCN}, \mathrm{NO}_{2}\right.$, I and $\mathrm{Br}$ ) (Aldrich, USA), were used as received from commercial sources. The solvents used in the reactions were of AR grade and were obtained from com- mercial sources (Merck, Germany). The solvents were dried using standard literature procedures. Microanalyses $(\mathrm{C}, \mathrm{H}, \mathrm{N})$ were performed on a Carlo-Ebra, EA 1108 instrument. Infrared spectra, as $\mathrm{KBr}$ pellets, were recorded in the range $4000-400 \mathrm{~cm}^{-1}$ on a Glaxy 7020 A spectrophotometer (Shimazdu Instruments Inc.). Electronic absorption spectra were recorded on a Shimadzu UV-Vis 265 spectrophotometer. ${ }^{1} \mathrm{H}-\mathrm{NMR}$ spectra were measured on a 400 $\mathrm{MHz}$ Bruker Instrument at room temperature; chemical shifts are given in ppm relative to TMS as an internal reference. Conductance measurements were performed in, $\mathrm{CHCl}_{3}$, DMSO and $\mathrm{H}_{2} \mathrm{O}$ solutions, using a HANNA instrument equipped with a HI $8820 \mathrm{~N}$ conductivity cell.

\section{Syntheses}

Ligands

The parent ligand salt $\mathrm{L} \cdot 2 \mathrm{HClO}_{4}$ was prepared by the method described in literature [22]. On reduction with sodium borohydrate, this ligand salt $\mathrm{L}^{2} 2 \mathrm{HClO}_{4}$ yielded two isomeric ligands, tet-a and tetb. The separation and isolation of the isomers tet-a and tet-b have been carried out as procedure adopted in the literature [23].

\section{Zinc(II) complexes}

Bimetallic mononitratozinc(II) and monometallic dinitratozinc(II) complexes

The nitratozinc(II) complexes; $\left[(\mathrm{ZnL})_{2}\left(\mathrm{NO}_{3}\right)\right]\left(\mathrm{ClO}_{4}\right)_{3}$, $[\mathrm{Zn}($ tet-a) $\left.\left(\mathrm{NO}_{3}\right)_{2}\right]$ and $\left[\mathrm{Zn}\left(\right.\right.$ tet-b) $\left.\left(\mathrm{NO}_{3}\right)_{2}\right]$ were prepared by the method described in our previous report [19].

Axial ligand addition and substitution products of nitratozinc(II) complexes

\section{Diisothiocyanatozinc(II) complexes}

Proper weight (2.0 mmol) of KSCN was dissolved in hot methanol $20 \mathrm{~mL}$ and then added to a hot methanolic suspension $(20 \mathrm{~mL})$ of each of the complexes, $\left[(\mathrm{ZnL})_{2}\left(\mathrm{NO}_{3}\right)\right]\left(\mathrm{ClO}_{4}\right)_{3},\left[\mathrm{Zn}(\right.$ tet-a $\left.)\left(\mathrm{NO}_{3}\right)_{2}\right]$ and $\left[\mathrm{Zn}\left(\right.\right.$ tet-b) $\left.\left(\mathrm{NO}_{3}\right)_{2}\right]$ in the molar ratio of $4: 1,2: 1$ and 2:1 respectively. The solutions were reduced to $15 \mathrm{~mL}$ by heating on a water bath, and then allowed to cool while the white product [ $\mathrm{Zn}(\mathrm{L})$ $\left.(\mathrm{NCS})_{2}\right]\left(\mathrm{L}^{\prime}=\mathrm{L}\right.$, tet-a or tet-b) crystallized out which was filtered off, washed with methanol followed by diethylether, and dried in a desiccator over silica gel.

[Zn(L)(NCS) $)_{2}$ ]: For $\mathrm{C}_{18} \mathrm{H}_{32} \mathrm{~N}_{6} \mathrm{~S}_{2} \mathrm{Zn}$ (462.01) Anal. calcd. (\%): C, 46.79; H, 6.98; N, 18.19; S, 13.88. Found, (\%): C, 46.77; H, 6.94; N, 18.23; S, 13.86. IR( $\left(v, \mathrm{~cm}^{-1}\right): 3157 v(\mathrm{~N}-\mathrm{H}), 2970 v(\mathrm{C}-\mathrm{H}), 1660$ 
$v(\mathrm{C}=\mathrm{N}), 1371 v\left(\mathrm{CH}_{3}\right), 1157 v(\mathrm{C}-\mathrm{C}), 2061 v(\mathrm{CN}), 848 v(\mathrm{CS}), 468$ $\delta(\mathrm{NCS}), 555 v(\mathrm{Zn}-\mathrm{N}) .{ }^{1} \mathrm{H}$ NMR $(\delta, \mathrm{ppm}):$ For $\mathrm{CH}_{3}, \delta=1.08$ (s, equatorial, $6 \mathrm{H}$ ), 1.14 (s, axial, $6 \mathrm{H}$ ), 2.10 (s, equatorial, $6 \mathrm{H}$ ); For $\mathrm{CH}_{2}, \mathrm{CH}$ and $\mathrm{NH}, \delta=2.61(\mathrm{~m}), 2.94(\mathrm{~m}), 3.22(\mathrm{~m})$. Molar conductivity $\left(\mathrm{ohm}^{-1}\right.$ $\mathrm{cm}^{2} \mathrm{~mole}^{-1}$ ): $\mathrm{CHCl}_{3}, 0$.

[Zn(tet-a)(NCS) $)_{2}$ ]: For $\mathrm{C}_{18} \mathrm{H}_{36} \mathrm{~N}_{6} \mathrm{~S}_{2} \mathrm{Zn}$ (466.04) Anal. calcd. (\%): C, 46.39; H, 7.79; N, 18.03; S, 13.76. Found (\%): C, 46.37; H, 7.70; N, 18.07; S, 13.80. IR ( $\left.v \mathrm{~cm}^{-1}\right): 3174 v(\mathrm{~N}-\mathrm{H}), 2968 v(\mathrm{C}-\mathrm{H}), 1382 v\left(\mathrm{CH}_{3}\right)$, $1161 v(\mathrm{C}-\mathrm{C}), 2058 v(\mathrm{CN}), 815 v(\mathrm{CS}), 480 \delta(\mathrm{NCS}), 542 v(\mathrm{Zn}-\mathrm{N})$. Molar conductivity $\left(\mathrm{ohm}^{-1} \mathrm{~cm}^{2} \mathrm{~mole}^{-1}\right): \mathrm{CHCl}_{3}, 0$.

[Zn(tet-b)(NCS) $)_{2}$ ]: For $\mathrm{C}_{18} \mathrm{H}_{36} \mathrm{~N}_{6} \mathrm{~S}_{2} \mathrm{Zn}(466.04)$ Anal. Calcd. (\%): C, 46.39; H, 7.79; N, 18.03; S, 13.76. Found (\%): C, 46.37; H, 7.77; N, 18.08; S, 13.81IR $\left(v, \mathrm{~cm}^{-1}\right): 3185 v(\mathrm{~N}-\mathrm{H}), 2970 v(\mathrm{C}-\mathrm{H}), 1376 v\left(\mathrm{CH}_{3}\right)$, $1165 v(\mathrm{C}-\mathrm{C}), 2075 v(\mathrm{CN}), 817 v(\mathrm{CS}), 460 \delta(\mathrm{NCS}), 556 v(\mathrm{Zn}-\mathrm{N}) .{ }^{1} \mathrm{H}$ $\operatorname{NMR}(\delta, \mathrm{ppm})$ : For $\mathrm{CH}_{3}, \delta=1.07$ (s, equatorial, $6 \mathrm{H}$ ), 1.29 (s, axial, $6 \mathrm{H}$ ), 1.11 (d, equatorial, $6 \mathrm{H}$ ); For $\mathrm{CH}_{2}, \mathrm{CH}$ and $\mathrm{NH}, \delta=1.65(\mathrm{~m})$, $2.40(\mathrm{~m}), 2.94(\mathrm{~m}), 3.06(\mathrm{~m}), 3.35(\mathrm{~m})$. Molar conductivity (ohm ${ }^{-1}$ $\left.\mathrm{cm}^{2} \mathrm{~mole}^{-1}\right): \mathrm{CHCl}_{3}, 0 ; \mathrm{H}_{2} \mathrm{O}, 49$.

\section{Nitrozinc(II) complexes}

The mononitrozinc(II) perchlorate complex, $\left[\mathrm{ZnL}\left(\mathrm{NO}_{2}\right)\right]\left(\mathrm{ClO}_{4}\right)$ and dinitrozinc(II) complexes, [Zn(tet-a) $\left.\left(\mathrm{NO}_{3}\right)_{2}\right]$ and [Zn(tet-b) $\left.\left(\mathrm{NO}_{3}\right)_{2}\right]$ were prepared by the procedure adopted for the preparation of diisothiocyanatozinc(II) complexes by using $\mathrm{KNO}_{2}$ instead of KSCN.

[ZnL( $\left.\mathbf{N O}_{2}\right)\left(\mathbf{C l O}_{4}\right)$ ]: For $\mathrm{C}_{16} \mathrm{H}_{32} \mathrm{~N}_{5} \mathrm{O}_{6} \mathrm{ClZn}$ (491.30) Anal. calcd. (\%): C, 39.11; H, 6.56; N, 14.25. Found (\%): C, 39.08; H, 6.50; N, 14.22. IR ( $\left.v, \mathrm{~cm}^{-1}\right): 3258 v(\mathrm{~N}-\mathrm{H}), 2970 v(\mathrm{C}-\mathrm{H}), 1664 v(\mathrm{C}=\mathrm{N}), 1381$ $v\left(\mathrm{CH}_{3}\right), 1159 v(\mathrm{C}-\mathrm{C}), 1448 v_{\text {asym }}\left(\mathrm{NO}_{2}\right), 1321 v_{\text {sym }}\left(\mathrm{NO}_{2}\right), 845 \delta\left(\mathrm{NO}_{2}\right)$, $1075,624, v\left(\mathrm{ClO}_{4}\right), 528 v(\mathrm{Zn}-\mathrm{N}) .{ }^{1} \mathrm{H} \mathrm{NMR}(\delta, \mathrm{ppm}):$ For $\mathrm{CH}_{3}, \delta=1.08$ (s, equatorial, $6 \mathrm{H}$ ), 1.11 (s, axial, $6 \mathrm{H}$ ), 2.09 (s, equatorial, $6 \mathrm{H}$ ); For $\mathrm{CH}_{2}, \mathrm{CH}$ and $\mathrm{NH}, \delta=2.50(\mathrm{~m}), 2.92(\mathrm{~m}), 3.24(\mathrm{~m})$. Molar conductivity $\left(\mathrm{ohm}^{-1} \mathrm{~cm}^{2} \mathrm{~mole}^{-1}\right): \mathrm{CHCl}_{3}, 0$; DMSO, 64; $\mathrm{H}_{2} \mathrm{O}, 224$.

[Zn(tet-a)( $\left.\mathrm{NO}_{2}\right)_{2}$ ]: For $\mathrm{C}_{16} \mathrm{H}_{36} \mathrm{~N}_{6} \mathrm{O}_{4} \mathrm{Zn}$ (441.88) Anal. calcd.(\%): C, 43.49; H, 8.21; N, 19.02. Found (\%): C, 43.52; H, 8.18; N, 19.07. IR ( $\left.v, \mathrm{~cm}^{-1}\right): 3186 v(\mathrm{~N}-\mathrm{H}), 2968 v(\mathrm{C}-\mathrm{H}), 1375 v\left(\mathrm{CH}_{3}\right), 1184 v(\mathrm{C}-\mathrm{C})$, $1460 v_{\text {asym }}\left(\mathrm{NO}_{2}\right), 1332 v_{\text {sym }}\left(\mathrm{NO}_{2}\right), 817 \delta\left(\mathrm{NO}_{2}\right), 525 v(\mathrm{Zn}-\mathrm{N})$. Molar conductivity $\left(\mathrm{ohm}^{-1} \mathrm{~cm}^{2} \mathrm{~mole}^{-1}\right): \mathrm{CHCl}_{3}, 0$; DMSO, 48; $\mathrm{H}_{2} \mathrm{O}, 181$.
[Zn(tet-b)( $\left.\mathrm{NO}_{2}\right)_{2}$ ]: For $\mathrm{C}_{16} \mathrm{H}_{36} \mathrm{~N}_{6} \mathrm{O}_{4} \mathrm{Zn}$ (441.88) Anal. calcd.(\%): C, 43.49; H, 8.21; N, 19.02. Found(\%): C, 43.46; H, 8.18; N, 19.06. IR( $\left(v, \mathrm{~cm}^{-1}\right): 3154 v(\mathrm{~N}-\mathrm{H}), 2947 v(\mathrm{C}-\mathrm{H}), 1354 v\left(\mathrm{CH}_{3}\right), 1184 v(\mathrm{C}-\mathrm{C})$, $1460 v_{\text {asym }}\left(\mathrm{NO}_{2}\right), 1354 v_{\text {sym }}\left(\mathrm{NO}_{2}\right), 845 \delta\left(\mathrm{NO}_{2}\right), 540 v(\mathrm{Zn}-\mathrm{N}) .{ }^{1} \mathrm{H}-\mathrm{NMR}$ $(\delta, \mathrm{ppm})$ : For $\mathrm{CH}_{3}, \delta=1.07$ (s, equatorial, $6 \mathrm{H}$ ), 1.27 (s, axial, $6 \mathrm{H}$ ), 1.11 (d, equatorial, $6 \mathrm{H}$ ); For $\mathrm{CH}_{2}, \mathrm{CH}$ and $\mathrm{NH}, \delta=2.41(\mathrm{~m}), 2.94(\mathrm{~m})$, 3.35 (m). Molar conductivity $\left(\mathrm{ohm}^{-1} \mathrm{~cm}^{2} \mathrm{~mole}^{-1}\right.$ ): $\mathrm{CHCl}_{3}, 0 ; \mathrm{H}_{2} \mathrm{O}, 35$.

\section{Diiodidozinc(II) complexes}

Diiodido complexes, [ZnLI $]$, [Zn(tet-a) $\left.\mathrm{I}_{2}\right]$ and $\left[\mathrm{Zn}\left(\right.\right.$ tet-b) $\left.\mathrm{I}_{2}\right]$ were afforded by following the procedure adopted for the preparation of diisothiocyanatozinc(II) complexes by using KBr instead of KSCN.

[ZnLI ] : For $\mathrm{C}_{16} \mathrm{H}_{32} \mathrm{~N}_{4} \mathrm{I} 2 \mathrm{Zn}(599.65)$ Anal. calcd. (\%): C, 32.05; H, 5.38; N, 9.34. Found (\%): C, 32.06; H, 5.41; N, 9.37 IR $\left(v, \mathrm{~cm}^{-1}\right): 3180$ $v(\mathrm{~N}-\mathrm{H}), 2966 v(\mathrm{C}-\mathrm{H}), 1668 v(\mathrm{C}=\mathrm{N}), 1373 v\left(\mathrm{CH}_{3}\right), 1160 v(\mathrm{C}-\mathrm{C}), 530$ $v(\mathrm{Zn}-\mathrm{N})$. Molar conductivity $\left(\mathrm{ohm}^{-1} \mathrm{~cm}^{2} \mathrm{~mole}^{-1}\right): \mathrm{CHCl}_{3}, 0$; DMSO, $90 ; \mathrm{H}_{2} \mathrm{O}, 280$.

[Zn(tet-a) $\mathrm{I}_{2}$ ]: For $\mathrm{C}_{16} \mathrm{H}_{36} \mathrm{~N}_{4} \mathrm{I} Z \mathrm{Zn}$ (603.68) Anal. calcd. (\%): C, 31.83; H, 6.01; N, 9.28. Found (\%): C, 31.80; H, 5.98; N, 9.26. IR(v, $\left.\mathrm{cm}^{-1}\right)$ : $3120 v(\mathrm{~N}-\mathrm{H}), 2962 v(\mathrm{C}-\mathrm{H}), 1376 v\left(\mathrm{CH}_{3}\right), 1182 v(\mathrm{C}-\mathrm{C}),(\mathrm{Zn}-\mathrm{N})$ $540 v .{ }^{1} \mathrm{H}$ NMR $(\delta, \mathrm{ppm})$ : For $\mathrm{CH}_{3}, \delta=1.15$ (s, equatorial, $6 \mathrm{H}$ ), 1.28 (s, axial, $6 \mathrm{H}$ ), 1.13 (d, equatorial, $6 \mathrm{H}$ ); For $\mathrm{CH}_{2}, \mathrm{CH}$ and $\mathrm{NH}, \delta=2.58$ (m), $2.86(\mathrm{~m}), 5.72(\mathrm{~m}), 6.51(\mathrm{~m})$. Molar conductivity $\left(\mathrm{ohm}^{-1} \mathrm{~cm}^{2}\right.$ mole $\left.{ }^{-1}\right): \mathrm{CHCl}_{3}, 0$; DMSO, 84; $\mathrm{H}_{2} \mathrm{O}, 282$.

[Zn(tet-b) $\mathrm{I}_{2}$ ]: For $\mathrm{C}_{16} \mathrm{H}_{36} \mathrm{~N}_{4} \mathrm{I}_{2} \mathrm{Zn}$ (603.68) Anal. calcd. (\%): C, 31.83; H, 6.01; N, 9.28. Found (\%): C, 31.79; H, 6.04; N, 9.29 IR (v, $\mathrm{cm}^{-1}$ ): $3121 v(\mathrm{~N}-\mathrm{H}), 2962 v(\mathrm{C}-\mathrm{H}), 1371 v\left(\mathrm{CH}_{3}\right), 1084 v(\mathrm{C}-\mathrm{C}), 545$ $v(\mathrm{Zn}-\mathrm{N})$. Molar conductivity $\left(\mathrm{ohm}^{-1} \mathrm{~cm}^{2} \mathrm{~mole}^{-1}\right): \mathrm{CHCl}_{3}, 0$; DMSO, 95; $\mathrm{H}_{2} \mathrm{O}, 286$.

\section{Dibromidozinc(II) complexes}

Dibromido complexes, [ $\left.\mathrm{ZnLBr}_{2}\right] \cdot 2 \mathrm{H}_{2} \mathrm{O},\left[\mathrm{Zn}\right.$ (tet-a) $\left.\mathrm{Br}_{2}\right] \cdot 2 \mathrm{H}_{2} \mathrm{O}$ and $\left[\mathrm{Zn}\left(\right.\right.$ tet-b) $\left.\mathrm{I}_{2}\right] \cdot 2 \mathrm{H}_{2} \mathrm{O}$ were furnished by the procedure adopted for the preparation of diisothiocyanatozinc(II) complexes by using $\mathrm{KBr}$ instead of KSCN.

[ZnLBr ${ }_{2}$ ].2H $2 \mathbf{H}_{2}$ O: For $\mathrm{C}_{16} \mathrm{~N}_{4} \mathrm{H}_{36} \mathrm{O}_{2} \mathrm{Br}_{2} \mathrm{Zn}$ (541.68) Anal. calcd. (\%): C, 35.48; H, 6.70; N, 10.34. Found (\%): C, 35.44; H, 6.73; N, 10.31 IR ( $\left.v, \mathrm{~cm}^{-1}\right): 3199 v(\mathrm{~N}-\mathrm{H}), 2970 v(\mathrm{C}-\mathrm{H}), 1662 v(\mathrm{C}=\mathrm{N}), 1373 v\left(\mathrm{CH}_{3}\right)$, $1159 v(\mathrm{C}-\mathrm{C}), 570,1652 v\left(\mathrm{H}_{2} \mathrm{O}\right), 3447 v(\mathrm{OH}), 548 v(\mathrm{Zn}-\mathrm{N})$. Molar conductivity $\left(\mathrm{ohm}^{-1} \mathrm{~cm}^{2} \mathrm{~mole}^{-1}\right): \mathrm{CHCl}_{3}, 0 ; \mathrm{H}_{2} \mathrm{O}, 191$. 
[Zn(tet-a)Br $\mathbf{B r}_{2}$.2 $\mathbf{H}_{2} \mathbf{0}$ : For $\mathrm{C}_{16} \mathrm{~N}_{4} \mathrm{H}_{40} \mathrm{O}_{2} \mathrm{Br}_{2} \mathrm{Zn}$ (545.71) Anal. calcd.: C, 35.21; H, 7.39; N, 10.27. Found: C, 35.25; H, 7.36 N, 10.25 IR $\left(v, \mathrm{~cm}^{-1}\right): 3153 v(\mathrm{~N}-\mathrm{H}), 2966 v(\mathrm{C}-\mathrm{H}), 1375 v\left(\mathrm{CH}_{3}\right), 1182, v(\mathrm{C}-\mathrm{C})$, $563,1620 v\left(\mathrm{H}_{2} \mathrm{O}\right), 3430 v(\mathrm{OH}), 552 v(\mathrm{Zn}-\mathrm{N}) .{ }^{1} \mathrm{H}$ NMR $(\delta, \mathrm{ppm})$ : For $\mathrm{CH}_{3}, \delta=1.07$ (s, equatorial, $6 \mathrm{H}$ ), 1.16 (s, axial, $6 \mathrm{H}$ ), 1.12 (d, equatorial, $6 \mathrm{H})$; For $\mathrm{CH}_{2}, \mathrm{CH}$ and $\mathrm{NH}, \delta=2.55(\mathrm{~m}), 2.91(\mathrm{~m}), 5.73(\mathrm{~m})$, $6.52(\mathrm{~m})$. Molar conductivity $\left(\mathrm{ohm}^{-1} \mathrm{~cm}^{2} \mathrm{~mole}^{-1}\right): \mathrm{CHCl}_{3}, 0$; DMSO, $36 ; \mathrm{H}_{2} \mathrm{O}, 241$.

[Zn(tet-b) $\mathrm{Br}_{2}$ ].2. $\mathbf{H}_{2} \mathbf{0}$ : For $\mathrm{C}_{16} \mathrm{~N}_{4} \mathrm{H}_{40} \mathrm{O}_{2} \mathrm{Br}_{2} \mathrm{Zn}$ (545.71) Anal. calcd. (\%): C, 35.21; H, 7.39; N, 10.27. Found: C, 35.19; H, 7.35; N, 10.29. IR $\left(v, \mathrm{~cm}^{-1}\right): 3121 v(\mathrm{~N}-\mathrm{H}), 2968 v(\mathrm{C}-\mathrm{H}), 1371 v\left(\mathrm{CH}_{3}\right), 1180 v(\mathrm{C}-\mathrm{C})$, $1636 v\left(\mathrm{H}_{2} \mathrm{O}\right), 3465 v(\mathrm{OH}), 540 v(\mathrm{Zn}-\mathrm{N}) .{ }^{1} \mathrm{H}$ NMR $(\delta, \mathrm{ppm}):$ For $\mathrm{CH}_{3}$, $\delta=1.08$ (s, equatorial, $6 \mathrm{H}), 1.26$ (s, axial, $6 \mathrm{H}), 1.12$ (d, equatorial, $6 \mathrm{H})$; For $\mathrm{CH}_{2}, \mathrm{CH}$ and NH, $\delta=2.45(\mathrm{~m}), 2.92(\mathrm{~m}), 3.08(\mathrm{~m}), 3.37(\mathrm{~m})$. Molar conductivity $\left(\mathrm{ohm}^{-1} \mathrm{~cm}^{2} \mathrm{~mole}^{-1}\right): \mathrm{CHCl}_{3}, 0 ; \mathrm{H}_{2} \mathrm{O}, 85$.

\section{Antibacterial activities}

Antibacterial activities of the ligands and their complexes against selected gram-positive and gram-negative bacteria were investigated by the disc diffusion method. Paper discs $(6 \mathrm{~mm}$ in diameter) and Petri plates (70 $\mathrm{mm}$ in diameter) were used throughout the experiment. Pour plates were made with sterilized melted nutrient agar NA $\left(45^{\circ} \mathrm{C}\right)$, and after solidification of the pour plates, the test organisms (suspension in DMSO) were spread uniformly over the pour plate with sterilized glass rod separately. The paper discs, after soaking with test chemicals $(1,1.5,2$ and $2.5 \mathrm{mg} / \mathrm{mL}$ in DMSO), were placed at the center of the inoculated pour plate. A control plate was also maintained in each case with DMSO. The plates firstly were kept for four hours at low temperature $\left(4^{\circ} \mathrm{C}\right)$ and the test chemicals diffused from the disc to the surrounding medium by this time. The plates were then incubated at $35 \pm$ $2)^{\circ} \mathrm{C}$ for the growth of the test organisms, and were observed at 24 hours and 48 hours intervals. But the activity did not differ between 24 hours and 48 hours intervals. The activity was expressed in terms of zone of inhibition in $\mathrm{mm}$. Test was repeated three times at 24-hours intervals for statistical analysis. As it was observed that activity of the compounds started at a concentration $2.5 \mathrm{mg} / \mathrm{mL}$, so activity of all compounds were reported at this concentration.

\section{Results and Discussion}

The concerned hexamethyltetraazamacrocyclic ligand salt L. $2 \mathrm{HClO}_{4}$ has been prepared and isomeric ligands of its reduced form, tet-a and tet-b have been isolated as per procedure adopted in the literature $[22,23]$ (Scheme 1). The bimetallic mononitratozinc(II) complex of $\mathrm{L},\left[(\mathrm{ZnL})_{2}\left(\mathrm{NO}_{3}\right)\right]\left(\mathrm{ClO}_{4}\right)_{3}$ and monometallic dinitratozinc(II) complexes of tet-a and tet-b, [Zn(tet-a) $\left.\left(\mathrm{NO}_{3}\right)_{2}\right]$ and $\left[\mathrm{Zn}\left(\right.\right.$ tet-b) $\left.\left(\mathrm{NO}_{3}\right)_{2}\right]$ have been prepared and characterized by different analytical data as well as by X-ray crystallography (Figure 1 and 2) as per our earlier report [18,19]. These
nitratozinc(II) complexes undergo axial ligand addition and substitution reactions to give a variety of trans-derivatives on reactions with $\mathrm{KX}\left(\mathrm{X}=\mathrm{SCN}, \mathrm{NO}_{2}\right.$, I or $\left.\mathrm{Br}\right)$ in proper ratio. These newly prepared compounds have been characterized by different analytical and spectroscopic techniques. All zinc(II) complexes were found white as expected and the melting points were above $250^{\circ} \mathrm{C}$. The stereo-chemistries of these complexes have been determined on the basis of ${ }^{1} \mathrm{H}-\mathrm{NMR}$ as well as on the basis that axial addition and substitution take place without change of configuration and conformation of ligands of the original zinc(II) complexes [19-21,24]. Since infrared spectra of these complexes could not be run at a range lower than $400 \mathrm{~cm}^{-1}$, so some IR bands due to metal-ligands (axial) stretch could not be recorded. However, conductance value $0 \mathrm{ohm}^{-1} \mathrm{~cm}^{2} \mathrm{~mole}^{-1}$ of these complexes in chloroform supported the formation of six coordinate non-electrolytic complexes. These zinc(II) complexes are found to be diamagnetic as expected for the presence of paired electrons in their $\mathrm{d}^{10}$ system. The electronic spectra of these complexes do not exhibit any $\mathrm{d}$-d band as expected for their $\mathrm{d}^{10}$ system.

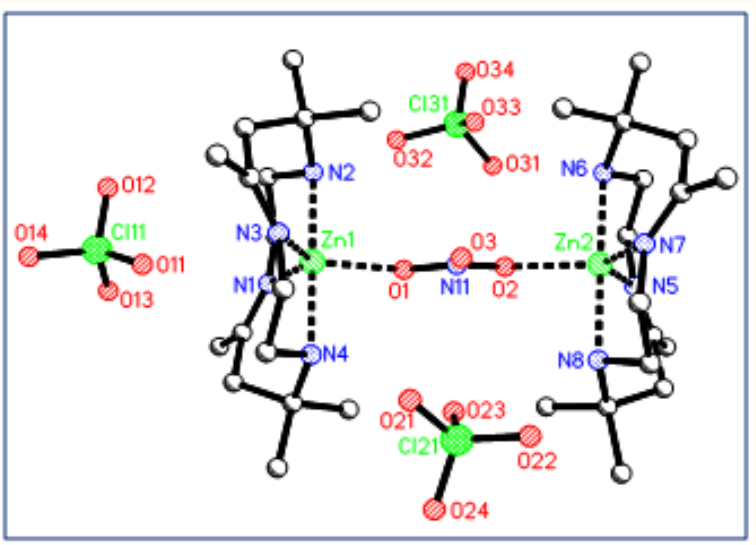

Figure 1: X-ray structure of $\left[(\mathrm{ZnL})_{2}\left(\mathrm{NO}_{3}\right)\right]\left(\mathrm{ClO}_{4}\right)_{3}$.

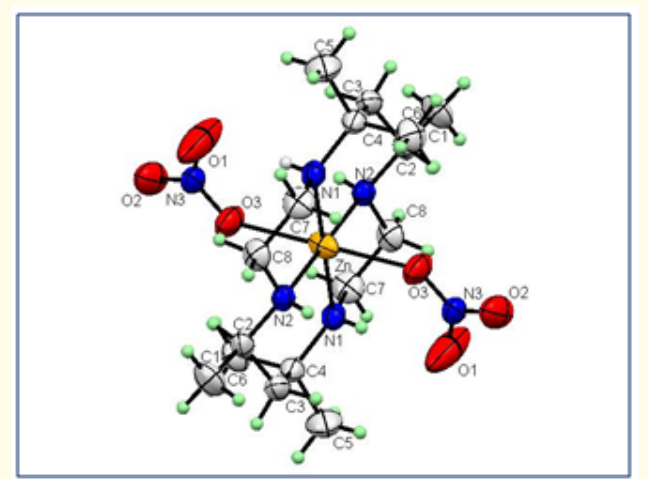

Figure 2: X-ray structure of $\left[\mathrm{Zn}(\right.$ tet-a $\left.)\left(\mathrm{NO}_{3}\right)_{2}\right]$. 


\section{Ligands}

The parent ligand $\mathrm{L}$ and two isomeric ligands, tet-a and tet-b were prepared and characterized as per literature [22,23].

\section{Zinc(II) complexes}

Bimetallic mononitratozinc(II) and monometallic dinitratozinc(II) complexes

The nitratozinc(II) complexes $\left[(\mathrm{ZnL})_{2}\left(\mathrm{NO}_{3}\right)\right]\left(\mathrm{ClO}_{4}\right)_{3}$, $[\mathrm{Zn}$ (tet-a) $\left.\left(\mathrm{NO}_{3}\right)_{2}\right]$ and $\left[\mathrm{Zn}\left(\right.\right.$ tet-b) $\left.\left(\mathrm{NO}_{3}\right)_{2}\right]$ were prepared and characterized as Structures I, II, and III (Chart 1) by the method described in our previous report [19].

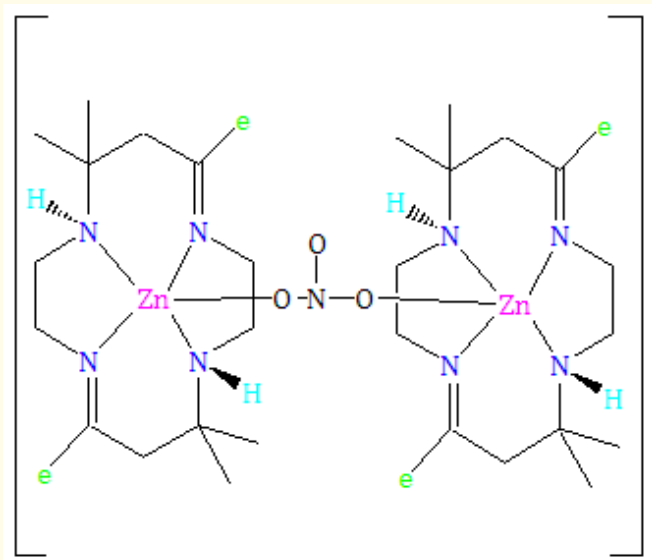

Str. I

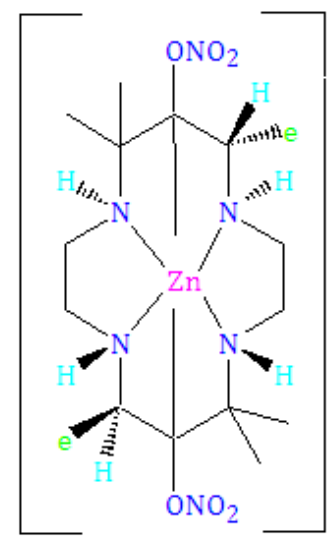

Str. II

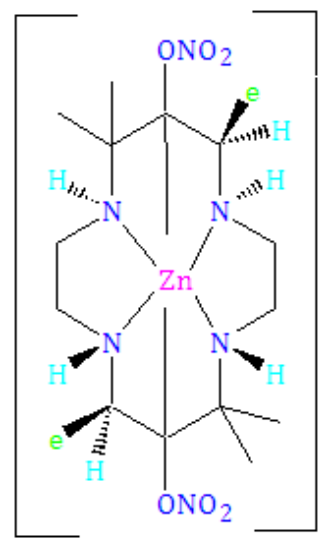

Str. III

\section{Chart 1}

\section{Isothiocyanatozinc(II) complexes}

Evaporation of the chloroform extracts of the products produced by the reactions of bimetallic $\left[(\mathrm{ZnL})_{2}\left(\mathrm{NO}_{3}\right)\right]\left(\mathrm{ClO}_{4}\right)_{3}$ and monometallic $\left[\mathrm{Zn}(\right.$ tet-a $\left.)\left(\mathrm{NO}_{3}\right)_{2}\right]$ and $\left[\mathrm{Zn}\left(\right.\right.$ tet-b) $\left.\left(\mathrm{NO}_{3}\right)_{2}\right]$ with KCNS in the proper ratio yielded white solid products $\left[\mathrm{Zn}(\mathrm{L})(\mathrm{NCS})_{2}\right],\left[\mathrm{Zn}\left(\right.\right.$ tet-a) $\left.(\mathrm{NCS})_{2}\right]$ and $\left[\mathrm{Zn}(\text { tet-b)(NCS)})_{2}\right]$ respectively. The infrared spectra of these isothiocyanato complexes show characteristic bands for $v(\mathrm{NH})$ at $3157-3185 \mathrm{~cm}^{-1}, v(\mathrm{C}-\mathrm{C})$ at 1157-1165 $\mathrm{cm}^{-1}, v(\mathrm{C}-\mathrm{H})$ at 2968-2970 $\mathrm{cm}^{-1}, v(\mathrm{Zn}-\mathrm{N})$ at $542-556 \mathrm{~cm}^{-1}$ and $v(\mathrm{C}=\mathrm{N})$ at $1660 \mathrm{~cm}^{-1}$ in case of $\left[\mathrm{Zn}(\mathrm{L})(\mathrm{NCS})_{2}\right]$. Absence of $v\left(\mathrm{NO}_{3}\right)$ bands and presence of $v(\mathrm{NCS})$ and $v(\mathrm{CN})$ bands demonstrate that the $\mathrm{NO}_{3}{ }^{-}$groups are substituted completely by $\mathrm{NCS}^{-}$groups. Additionally in case of $\left[(\mathrm{ZnL})_{2}\left(\mathrm{NO}_{3}\right)\right]$ $\left(\mathrm{ClO}_{4}\right)_{3}$, simultaneous substitution of $\mathrm{NO}_{3}{ }^{-}$ion and addition of NCS- ion has taken place to form a monometallic complex from a bimetallic complex. Evidence in favor of co-ordination of NCS- ion through $\mathrm{N}$-atoms comes from the infrared spectra of these complexes. As per literature [26], since zinc is an element of $1^{\text {st }}$ transition series, it is expected that NCS group in these complexes, will be bonded through the nitrogen atom of thiocyanate group. Appearance of sharp $v(\mathrm{CN})$ band in the region of 2058-2075 $\mathrm{cm}^{-1}$ in the present complexes is a good indication of N-bonded thiocya- 
nate group $[25,26]$. The present complexes also displays $v_{\mathrm{CS}}$ bands at $815-846 \mathrm{~cm}^{-1}$ and $\delta_{(\mathrm{NCS})}$ bands at $460-480 \mathrm{~cm}^{-1}$ which do not correspond to ligand in this region and are therefore assigned for fully N-bonded thiocyanate group [26-30]. Therefore, these complexes can be identified as isothiocyanato complexes. Molar conductivity value of $0 \mathrm{ohm}^{-1} \mathrm{~cm}^{2} \mathrm{~mole}^{-1}$ in chloroform indicates that these complexes are non electrolytic in nature, i.e. the anions are in the coordination sphere as expected for six coordinated octahedral diisothiocyanatozinc(II) complexes. The ${ }^{1} \mathrm{H}-\mathrm{NMR}$ spectrum of $\left[\mathrm{ZnL}(\mathrm{NCS})_{2}\right]$ exhibits three singlets at $1.08 \mathrm{ppm}, 1.14 \mathrm{ppm}$ and 2.10 ppm corresponding to $6 \mathrm{H}$ each. These singlets can be assigned to equatorial and axial components of gem dimethyl groups and equatorial methyl protons on double bonded $\mathrm{sp}^{2}$ carbons. Appearance of multiplets at 2.61, 2.94 and 3.22 ppm can be accounted for $\mathrm{CH}_{2}$, $\mathrm{CH}$ and $\mathrm{NH}$ protons. The spectral pattern is similar to its mother complex, $\left[(\mathrm{ZnL})_{2}\left(\mathrm{NO}_{3}\right)\right]\left(\mathrm{ClO}_{4}\right)_{3}$. This proves that axial addition and substitution take place without change of configuration and conformation of ligand of original mother complex. The ${ }^{1} \mathrm{H}-\mathrm{NMR}$ spectrum of the diisothiocyanotozinc(II) complex of tet-b, [Zn(tet-b) $(\mathrm{NCS})_{2}$ ] displays two singlets. The singlets at $1.07 \mathrm{ppm}$ and 1.29 ppm each corresponding to six protons can be assigned to equatorial and axial components of the gem-dimethyl groups respectively. The spectrum further reveals one doublet at 1.10 ppm corresponding to $6 \mathrm{H}$, which can be assigned to equatorially oriented methyl protons on $\mathrm{C}_{5}$ and $\mathrm{C}_{12}$ chiral carbons. The spectrum also shows some downfield multiplets at 1.65, 2.40, 2.94, 3.06 and 3.35 ppm due to $\mathrm{CH}_{2}, \mathrm{CH}$ and $\mathrm{NH}$ protons. Regarding stereochemistry of this complex, a di-equatorial orientation of chiral methyls has been assigned as Structure IV of chart 2, which is a trans-III type of structure and most stable one [31] having the same stereochemistry of its mother complex, $\left[\mathrm{Zn}\left(\right.\right.$ tet-b) $\left.\left(\mathrm{NO}_{3}\right)_{2}\right]$. The spectral pattern of this complex is similar to the corresponding dichloridocobalt(III) complex [32] and the same assignment has also been made for the corresponding six coordinated cobalt(III) complexes. However stereochemistry of other complex [Zn(tet-a)(NCS) ${ }_{2}$ (Structure V, Chart 2) has been assigned as its mother complex based on the fact as mentioned earlier regarding axial substitution [19-21,24]. Based on the above evidences, the following structures, IV, V, and VI (Chart 1) can be assigned for $\left[\mathrm{Zn}(\mathrm{L})(\mathrm{NCS})_{2}\right]$, [Zn(tet-a)(NCS $\left.)_{2}\right]$ and $[\mathrm{Zn}($ tet-b) $(\mathrm{NCS})_{2}$ ] respectively.

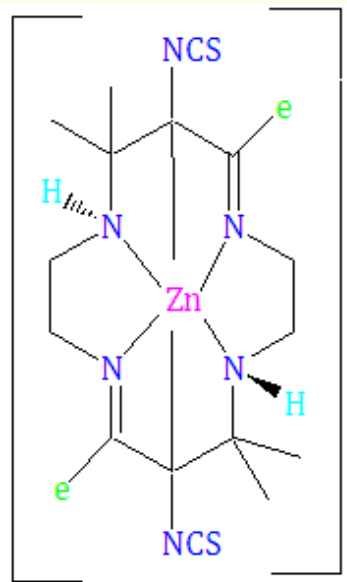

Str. IV

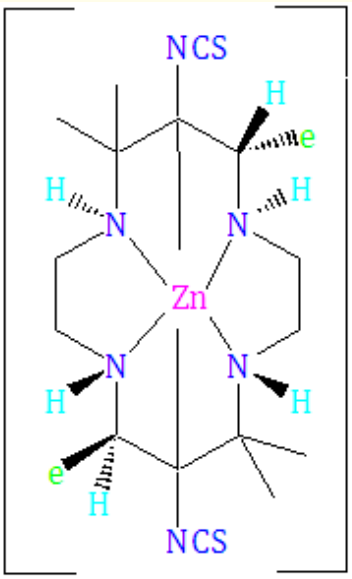

Str. V

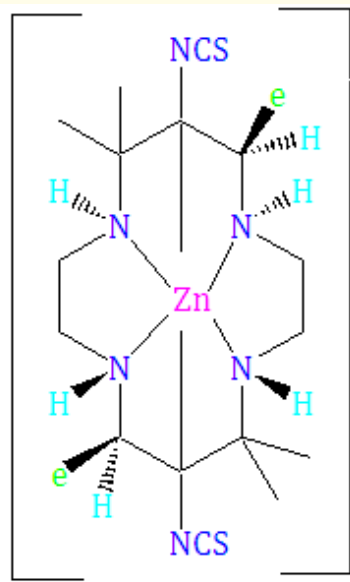

Str. VI

Chart 2

Citation: Tapashi Ghosh Roy., et al. "Tetraazamacrocyclic Ligands and their Zinc(II) Complexes: Synthesis, Characterization and Biological Activities”. Acta Scientific Pharmaceutical Sciences 4.8 (2020): 42-54. 


\section{Nitro complexes}

Reactions of $\left[(\mathrm{ZnL})\left(\mathrm{NO}_{3}\right)_{2}\right]\left(\mathrm{ClO}_{4}\right)_{3}, \quad\left[\mathrm{Zn}(\right.$ tet-a $\left.)\left(\mathrm{NO}_{3}\right)_{2}\right]$ and [Zn(tet-b) $\left(\mathrm{NO}_{3}\right)_{2}$ ] with $\mathrm{KNO}_{2}$ in methanolic solution resulted white mass in each case, which after extraction with chloroform and evaporation of solvent afforded white solid products $\left[\mathrm{ZnL}\left(\mathrm{NO}_{2}\right)\right.$ $\left.\left(\mathrm{ClO}_{4}\right)\right],\left[\mathrm{Zn}(\right.$ tet-a $\left.)\left(\mathrm{NO}_{2}\right)_{2}\right]$ and $\left[\mathrm{Zn}\left(\right.\right.$ tet-b) $\left.\left(\mathrm{NO}_{2}\right)_{2}\right]$ respectively. Infrared spectra of these complexes show $v(\mathrm{~N}-\mathrm{H}), v(\mathrm{C}-\mathrm{H}), v\left(\mathrm{CH}_{3}\right)$, $v(\mathrm{C}-\mathrm{C})$ and $v(\mathrm{Zn}-\mathrm{N})$ stretching bands at the expected regions. Moreover the complexes exhibit the $v_{\text {asym }}\left(\mathrm{NO}_{2}\right)$ and $v_{\text {sym }}\left(\mathrm{NO}_{2}\right)$ bands at $1448-1460 \mathrm{~cm}^{-1}$ and $1321-1354 \mathrm{~cm}^{-1}$ respectively. Appearance of bands at $817-845 \mathrm{~cm}^{-1}$ can be attributed to $\delta_{\mathrm{NO} 2}$ frequency. The spectrum of $\left[\mathrm{ZnL}\left(\mathrm{NO}_{2}\right)\left(\mathrm{ClO}_{4}\right)\right]$ exhibits additional bands at 1075 $\mathrm{cm}^{-1}$ and $624 \mathrm{~cm}^{-1}$ which demonstrates the presence of $\mathrm{ClO}_{4}$ group. The splitting of band at $1075 \mathrm{~cm}^{-1}$ is an indication of coordination of $\mathrm{ClO}_{4}$. Presence of $v(\mathrm{Zn}-\mathrm{N})$ band at $432-443 \mathrm{~cm}^{-1}$ and other bands in the proper region support the complexes to be $\mathrm{N}$-bonded nitro complexes. Molar conductivity value $0 \mathrm{ohm}^{-1} \mathrm{~cm}^{2} \mathrm{~mole}^{-1}$ of the complexes in chloroform indicates that the complexes are nonelectrolyte in nature. However for the complexes $\left[(\mathrm{ZnL})\left(\mathrm{NO}_{2}\right)\left(\mathrm{ClO}_{4}\right)\right]$ and [Zn(tet-a) $\left.\left(\mathrm{NO}_{2}\right)_{2}\right]$, conductance values of $48 \& 64 \mathrm{ohm}^{-1} \mathrm{~cm}^{2} \mathrm{~mole}^{-1}$ in DMSO and $181 \& 224 \mathrm{ohm}^{-1} \mathrm{~cm}^{2} \mathrm{~mole}^{-1}$ in water corresponding to $1: 1$ [33] and 1:2 electrolytes respectively are probably due to the replacement of nitrite ion by DMSO and $\mathrm{H}_{2} \mathrm{O}$ from the coordination sphere respectively. Thus 1:1 electrolytes in DMSO can be assigned for equilibrium between original octahedral complexes with square pyramidal $[\mathrm{ZnL}(\mathrm{DMSO})]\left(\mathrm{NO}_{2}\right)\left(\mathrm{ClO}_{4}\right)$ and $[\mathrm{Zn}$ (tet-a) (DMSO)] $\left(\mathrm{NO}_{2}\right)_{2}$; or with octahedral $\left[\mathrm{ZnL}\left(\mathrm{DMSO}_{2}\right]\left(\mathrm{NO}_{2}\right)\left(\mathrm{ClO}_{4}\right)\right.$ and [Zn(tet-a)(DMSO) $\left.)_{2}\right]\left(\mathrm{NO}_{2}\right)_{2}$ complexes respectively. But it is more likely to assign a square pyramidal $[\mathrm{ZnL}(\mathrm{DMSO})]\left(\mathrm{NO}_{2}\right)\left(\mathrm{ClO}_{4}\right)$ and [Zn(tet-a)(DMSO)] $\left(\mathrm{NO}_{2}\right)_{2}$. Since for the formation of octahedral geometry, two big DMSO molecules should be incorporated into the cavity which is also not favorable, so only square pyramidal [ZnL(DMSO)] $\left(\mathrm{NO}_{2}\right)\left(\mathrm{ClO}_{4}\right)$ or $\left[\mathrm{Zn}(\right.$ tet-a) $(\mathrm{DMSO})]\left(\mathrm{NO}_{2}\right)_{2}$ (expression 01 and 02) structure is comparatively favorable. These replacement reactions can be expressed by the expressions 01 and 02:

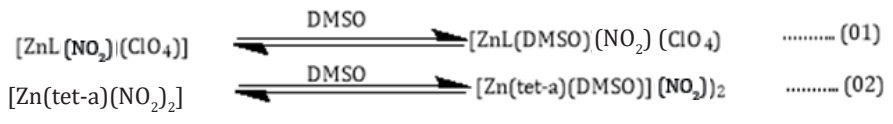

The other option is that DMSO may force one of the counter ions to come out from the coordination site to form a square pyramidal complex which can be expressed by the expressions
03 and 04 . This option is more favorable for solvent DMSO as it does not entertain the incorporation of a big molecule like DMSO:

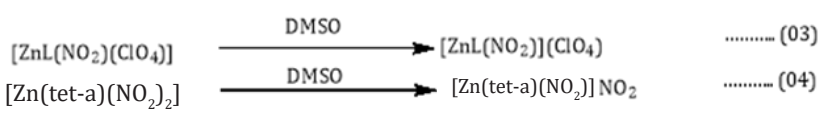

However, the 1:2 electrolytic behavor of these complexes can be accounted for conversion of them into diaqua species of the same geometry as expressed by the expressions 05 and 06:

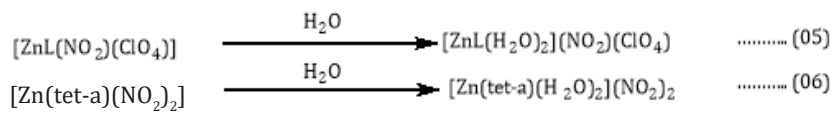

Again the conductance value $35 \mathrm{ohm}^{-1} \mathrm{~cm}^{2}$ mole $^{-1}$ of [Zn(tet-b) $\left.\left(\mathrm{NO}_{2}\right)_{2}\right]$ in water also corresponds to that of nonelectrolytes. The ${ }^{1} \mathrm{H}-\mathrm{NMR}$ spectrum of $\left[\mathrm{ZnL}\left(\mathrm{NO}_{2}\right)\left(\mathrm{ClO}_{4}\right)\right]$ shows the same spectral pattern like parent complex $\left[(\mathrm{ZnL})\left(\mathrm{NO}_{3}\right)_{2}\right]\left(\mathrm{ClO}_{4}\right)_{3}$. This observation is quite reasonable since the axial addition and substitution take place without change of configuration and conformation of ligand of original complex. Thus the ${ }^{1} \mathrm{H}-\mathrm{NMR}$ spectrum of $\left[\mathrm{ZnL}\left(\mathrm{NO}_{2}\right)\right.$ $\left(\mathrm{ClO}_{4}\right)$ shows four sharp methyl singlets at $1.08 \mathrm{ppm}, 1.11 \mathrm{ppm}$, $2.09 \mathrm{ppm}$ and $2.50 \mathrm{ppm}$. The singlet corresponding to six protons at $1.08 \mathrm{ppm}$ can be assigned to a pair of equatorial methyls of the gem-dimethyl groups and the one at $1.11 \mathrm{ppm}$ can be assigned for a pair of axial methyls $(6 \mathrm{H})$ of the gem-dimethyl groups. The singlet at $2.09 \mathrm{ppm}$ can be assigned to two equatorially oriented imine methyls at $\mathrm{C}_{5}$ and $\mathrm{C}_{12}$. However, the singlet at $2.50 \mathrm{ppm}$ corresponding to four protons can be assigned to the peak arising out of methylene protons at $\mathrm{C}_{6}$ and $\mathrm{C}_{13}$. The spectrum further exhibits multiplets at $2.65 \mathrm{ppm}, 2.92 \mathrm{ppm}$ and $3.24 \mathrm{ppm}$ which may be attributed to other $\mathrm{CH}_{2}$ and $\mathrm{NH}$ protons. The spectral pattern is same as parent complex $\left[(\mathrm{ZnL})_{2}\left(\mathrm{NO}_{3}\right)\right]\left(\mathrm{ClO}_{4}\right)_{3}[19]$. The ${ }^{1} \mathrm{H}-\mathrm{NMR}$ spectrum of $\left[\mathrm{Zn}\left(\right.\right.$ tet-b) $\left.\left(\mathrm{NO}_{2}\right)_{2}\right]$ displays two singlets due to axial and equatorial components of gem dimethyl protons, one doublet for equatorially oriented two methyl protons on two chiral carbons and multiplets for $\mathrm{CH}_{2}$, $\mathrm{CH}$ and $\mathrm{NH}$ protons. This spectral pattern is similar to original complex $\left[\mathrm{Zn}(\right.$ tet-b $\left.)\left(\mathrm{NO}_{3}\right)_{2}\right]$ and its corresponding isothiocyanato complex [Zn(tet-b)(NCS)$)_{2}$. Thus the same stereochemistry (trans-III form, stable $\mathrm{N}$-isomer) has been assigned to this derivative. Thus the structures VII, VIII and IX (Chart 3) can be assigned for $\left[\mathrm{ZnL}\left(\mathrm{NO}_{2}\right)\left(\mathrm{ClO}_{4}\right)\right]$, $\left[\mathrm{Zn}(\right.$ tet-a $\left.)\left(\mathrm{NO}_{2}\right)_{2}\right]$ and $[\mathrm{Zn}($ tet-b) $\left.\left(\mathrm{NO}_{2}\right)_{2}\right]$ respectively. 


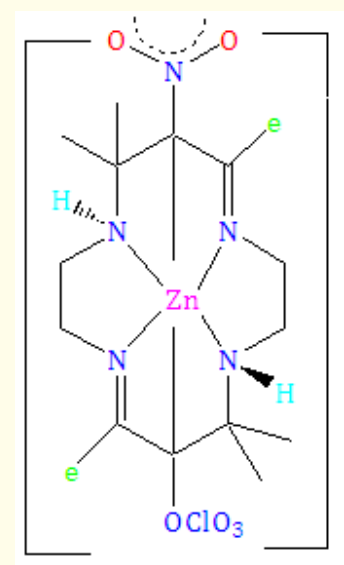

Str. VII

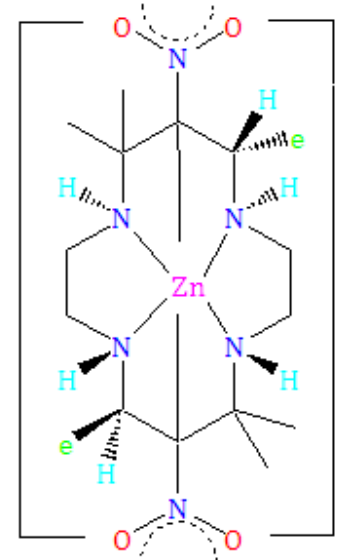

Str. VIII

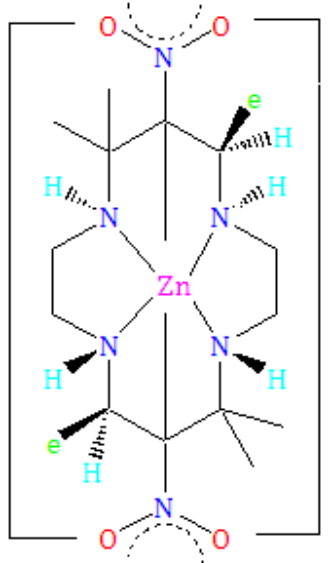

Str. IX

\section{Chart 3}

\section{Diiodidozinc(II) complexes}

The complex, $\left[(\mathrm{ZnL})_{2}\left(\mathrm{NO}_{3}\right)\right]\left(\mathrm{ClO}_{4}\right)_{3}$ in the ratio of $1: 4$ and $[\mathrm{Zn}$ (teta) $\left.\left(\mathrm{NO}_{3}\right)_{2}\right]$ and $\left[\mathrm{Zn}\left(\right.\right.$ tet-b) $\left.\left(\mathrm{NO}_{3}\right)_{2}\right]$ in the ratio of $1: 2$ on reaction with KI gave white mass and extraction of these products with chloroform and evaporation of solvent produced white products $\left[\mathrm{ZnLI}_{2}\right]$, $\left[\mathrm{Zn}\left(\right.\right.$ tet-a $\left.\mathrm{I}_{2}\right]$ and $\left[\mathrm{Zn}\left(\right.\right.$ tet-b) $\left.\mathrm{I}_{2}\right]$ respectively. Infrared spectra of these complexes exhibit $v(\mathrm{~N}-\mathrm{H}), v(\mathrm{C}-\mathrm{H}), v\left(\mathrm{CH}_{3}\right), v(\mathrm{C}-\mathrm{C})$ and $v(\mathrm{Zn}-\mathrm{N})$ bands at expected region. Since the IR spectra could not be run below $400 \mathrm{~cm}^{-1}$, Zn-I stretch could not be detected for these complexes. Molar conductivity value $0 \mathrm{ohm}^{-1} \mathrm{~cm}^{2} \mathrm{~mole}^{-1}$ of these complexes in chloroform support the non-electrolytic nature of theses complexes, i.e. both the iodide ions are coordinated to zinc(II) ions. However the conductance values of $90,84 \& 95 \mathrm{ohm}^{-1} \mathrm{~cm}^{2} \mathrm{~mole}^{-1}$ in DMSO and 280, $282 \& 286 \mathrm{ohm}^{-1} \mathrm{~cm}^{2} \mathrm{~mole}^{-1}$ in water corresponding to $1: 1$ [33] and 1:2 electrolytes respectively are probably due to conversion of octahedral species $\left[\mathrm{ZnL}_{2} \mathrm{I}_{2}\right]\left(\mathrm{L}^{\prime}=\mathrm{L}\right.$, tet-a or tet-b) to square pyradimidal species [ZnL'I]I (L'= L, tet-a or tet-b) (expression 07) in DMSO and conversion of diiodido derivatives [ZnL'I $\left.\mathrm{I}_{2}\right]$ to diaqua species $\left[\mathrm{ZnL}\left(\mathrm{H}_{2} \mathrm{O}\right)_{2}\right] \mathrm{I}_{2}$ (expression 08) in $\mathrm{H}_{2} \mathrm{O}$ respectively. These conversions can be expressed by the following expressions
07 and 08 as discussed in earlier section:

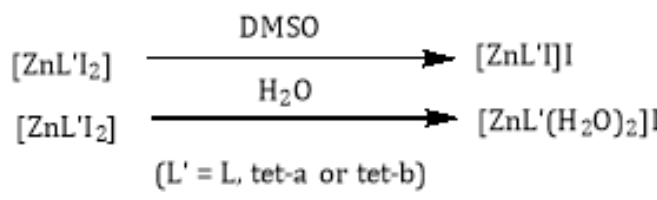

The ${ }^{1} \mathrm{H}-\mathrm{NMR}$ spectrum of $\left[\mathrm{Zn}\left(\right.\right.$ tet-a) $\left.\mathrm{I}_{2}\right]$ displays two singlets at 1.15 and $1.28 \mathrm{ppm}$ each corresponding to $6 \mathrm{H}$ which can be accounted for equatorial and axial components of gem- dimethyl protons. The spectrum further exhibits one doublet at $1.13 \mathrm{ppm}$ corresponding to $6 \mathrm{H}$ which can be attributed to equatorially orientated two methyl protons on two chiral carbons. Thus a diequtorial orientation of chiral methyl has been assigned like the original mother complex $\left[\mathrm{Zn}(\right.$ tet-a $\left.)\left(\mathrm{NO}_{3}\right)_{2}\right]$ which also proves the retention of configuration and conformation of ligands in substitution products $[20,21,24]$. The spectrum also provides some downfield multiplets due to $\mathrm{CH}_{2}, \mathrm{CH}$ and $\mathrm{NH}$ protons. So on the basis of the above discussion the following structures X, XI and XII (Chart 4) can be proposed for $\left[\mathrm{ZnLI}_{2}\right]\left[\mathrm{Zn}\left(\right.\right.$ tet-a) $\left.\mathrm{I}_{2}\right]$ and $\left[\mathrm{Zn}\left(\right.\right.$ tet-b) $\left.\mathrm{I}_{2}\right]$ complexes re- 


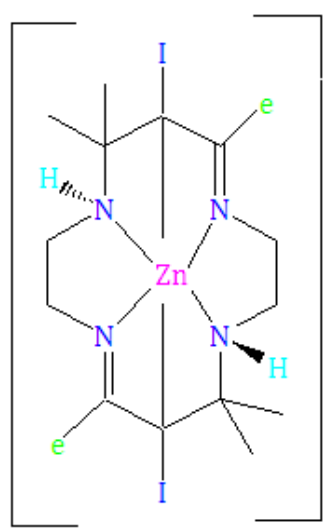

Str. X

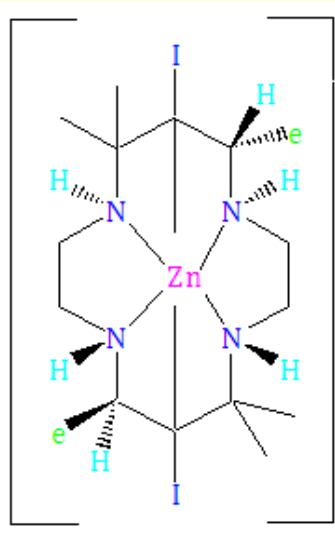

Str. XI

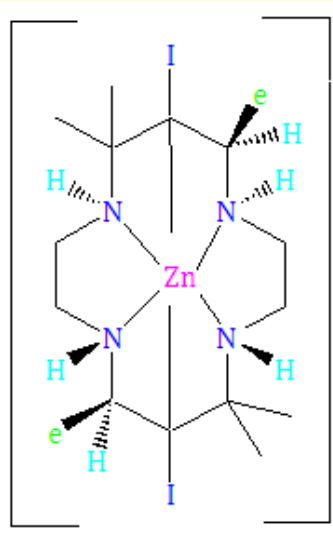

Str. XII

\section{Chart 4}

spectively.

\section{Dibromidozinc(II) complexes}

The complexes $\left[\mathrm{ZnLBr}_{2}\right] \cdot 2 \mathrm{H}_{2} \mathrm{O}$, [Zn(teta) $\left.\mathrm{Br}_{2}\right] \cdot 2 \mathrm{H}_{2} \mathrm{O}$ and [Zn(teta) $\left.\mathrm{Br}_{2}\right] \cdot 2 \mathrm{H}_{2} \mathrm{O}$, were resulted by the reactions of $\mathrm{KBr}$ with $\left[(\mathrm{ZnL})_{2}\left(\mathrm{NO}_{3}\right)\right]$ $\left(\mathrm{ClO}_{4}\right)_{3},\left[\mathrm{Zn}(\right.$ tet-a $\left.)\left(\mathrm{NO}_{3}\right)_{2}\right]$ and $\left[\mathrm{Zn}\left(\right.\right.$ tet-b) $\left.\left(\mathrm{NO}_{3}\right)_{2}\right]$ respectively. The infrared spectra of these complexes exhibit all characteristic bands due to $v(\mathrm{~N}-\mathrm{H}), v(\mathrm{C}-\mathrm{H}), v\left(\mathrm{CH}_{3}\right), v(\mathrm{C}-\mathrm{C})$ and $v(\mathrm{Zn}-\mathrm{N})$ stretching bands in the proper positions. The IR spectra of these complexes also exhibit $v\left(\mathrm{H}_{2} \mathrm{O}\right)$ bands at $1620-1652 \mathrm{~cm}^{-1}$ and $\mathrm{v}(\mathrm{OH})$ bands at $3430-3465 \mathrm{~cm}^{-1}$ which indicates the presence of lattice water [30]. Since the IR spectra could not be run below $400 \mathrm{~cm}^{-1}, \mathrm{Zn}-\mathrm{Br}$ stretch could not be detected for these complexes. Molar conductivity value $0 \mathrm{ohm}^{-1} \mathrm{~cm}^{2}$ mole $^{-1}$ of these complexes in chloroform indicates that the complexes are nonelectrolytes in nature. However the conductance values of 191 and $241 \mathrm{ohm}^{-1} \mathrm{~cm}^{2} \mathrm{~mole}^{-1}$ of $\left[\mathrm{ZnLBr}_{2}\right] \cdot 2 \mathrm{H}_{2} \mathrm{O}$ and $\left[\mathrm{Zn}\right.$ (tet-a) $\left.\mathrm{Br}_{2}\right] \cdot 2 \mathrm{H}_{2} \mathrm{O}$ in water corresponding to $1: 2$ electrolyte can be accounted for the replacement of bromide ions by $\mathrm{H}_{2} \mathrm{O}$ molecules from the coordination sphere (expression-09):

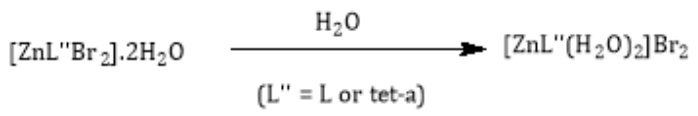

Again the conductance value of $36 \mathrm{ohm}^{-1} \mathrm{~cm}^{2} \mathrm{~mole}^{-1}$ of the complex $\left[\mathrm{Zn}\left(\right.\right.$ tet-a) $\left.\mathrm{Br}_{2}\right] \cdot 2 \mathrm{H}_{2} \mathrm{O}$ in DMSO also supports its nonelectrolytic nature as expected. However, the conductance value of $85 \mathrm{ohm}^{-1} \mathrm{~cm}^{2} \mathrm{~mole}^{-1}$ of this complex corresponding to $1: 1$ electrolyte can be attributed to equilibrium between its present form and its diaqua species as per expression-10:

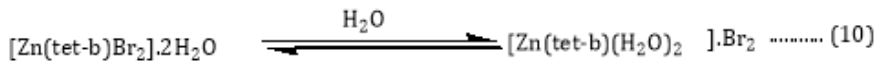

The ${ }^{1} \mathrm{H}-\mathrm{NMR}$ spectra of $\left[\mathrm{Zn}\right.$ (tet-a)Br $\left.\mathrm{Br}_{2}\right]$ and $\left[\mathrm{Zn}\right.$ (tet-b)Br $\left.\mathrm{Br}_{2}\right]$ show the similar spectral pattern like their original mother complex, $\left[\mathrm{Zn}\left(\right.\right.$ tet-a) $\left.\left(\mathrm{NO}_{3}\right)_{2}\right]$ and $\left[\mathrm{Zn}\left(\right.\right.$ tet-b) $\left.\left(\mathrm{NO}_{3}\right)_{2}\right]$ respectively $[19,20]$. From the afore mentioned evidences, the following structures XIII, XIV and XV (Chart 5) have been assigned to $\left[\mathrm{ZnLBr}_{2}\right] \cdot 2 \mathrm{H}_{2} \mathrm{O}$, [Zn(tet-a) $\left.\mathrm{Br}_{2}\right] \cdot 2 \mathrm{H}_{2} \mathrm{O}$ and [ $\mathrm{Zn}$ (tet-b) $\left.\mathrm{Br}_{2}\right] \cdot 2 \mathrm{H}_{2} \mathrm{O}$ respectively.

\section{Antibacterial activities}

Studies on antibacterial activities of the metal complexes of different macrocyclic ligands [34-37] as well as with concerned ligands [19-21] have been reported in the literature. Antibacterial activities against different gram positive and gram negative bacteria of some zinc(II) complexes have also been reported [19]. But axial substitution and addition products of zinc(II) complexes with concerned macrocycles L, tet-a and tet-b have not been studied so far. So, it was interesting to examine whether these addition and 
substitution complexes show any such activity or not. In this context, antibacterial activities of these ligands and axial substitution and addition products of some nitratozinc(II) complexes have been carried out against two important gram-positive bacteria Bacillus cereus and Bacillus megaterium and five gram-negative bacteria, Salmonella typhi, Escherichia coli, Shigella sonnei, Klebsiella pneumonia, Pseudomonas aeruginosa. To test the minimum concentration, at which the antibacterial activity starts, the antibacterial activities were carried out at the concentration of $1,1.5,2,2.5 \mathrm{mg} / \mathrm{mL}$. However, these compounds were found to start showing activity from concentration $2.5 \mathrm{mg} / \mathrm{mL}$ as our earlier reports [19]. So, the whole antibacterial study was performed at this concentration al- though our other earlier studies [20,34-36] were carried out at the concentration of $1 \mathrm{mg} / \mathrm{mL}$. The results (Table 1 and 2) reveal that, the ligands are ineffective against all bacteria, but all of its complexes exhibit mentionable antibacterial activity as our previous studies [19,20,34-36]. Both mononitrozinc(II) complex of diene ligand $\mathrm{L}$ and diiodidozinc(II) of tet-a show a promising activity (Table 1), against concerned gram positive bacteria but diiodidozinc(II) complex of tet-a is totally ineffective against gram negative bacteria $S$. sonnei, K. pneumonia and P. aeruginosa (Table 2). Dibromido complex of L exhibits good activity against B. megaterium but ineffective against $B$. cereus, on the other hand dibromidozinc(II) complex of tet-a reveals no activity against both gram positive bacteria but

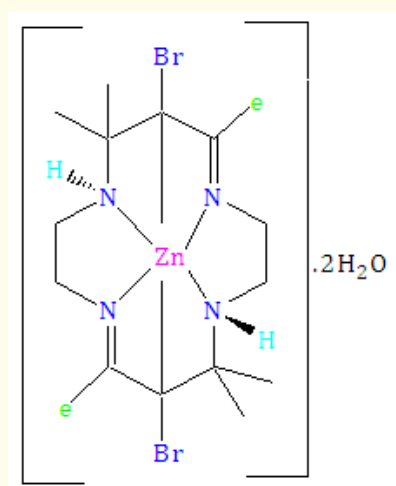

Str. XIII

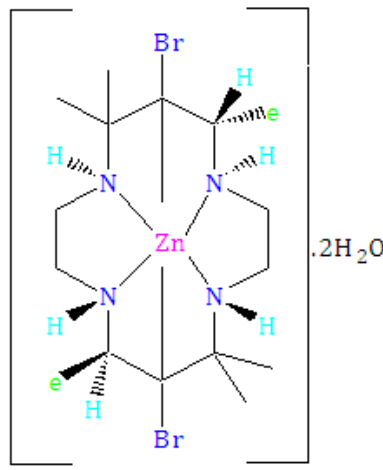

Str. XIV

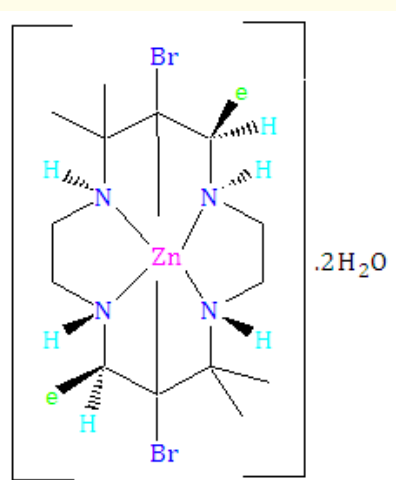

Str. XV

Chart 5

Table 1: Antibacterial activity of the compounds against gram positive bacteria.

\begin{tabular}{|c|c|c|}
\hline \multirow{2}{*}{ Name of the compounds } & \multicolumn{2}{|c|}{ Inhibition zone of the compounds (mm) } \\
\hline & B. megaterium & B. cereus \\
\hline L. $2 \mathrm{HClO}_{4}$ & 0 & 0 \\
\hline tet-a & 0 & 0 \\
\hline tet-b & 0 & 0 \\
\hline$\left[\mathrm{ZnL}(\mathrm{NCS})_{2}\right]$ & 8 & 9 \\
\hline$\left[\right.$ Zn(tet-a) $\left.(\mathrm{NCS})_{2}\right]$ & 11 & 15 \\
\hline$\left[\mathrm{Zn}\left(\right.\right.$ tet-b) $\left.(\mathrm{NCS})_{2}\right]$ & 6 & 0 \\
\hline$\left[\mathrm{ZnL}\left(\mathrm{NO}_{2}\right)\right]\left(\mathrm{ClO}_{4}\right)$ & 24 & 22 \\
\hline$\left[\mathrm{Zn}(\right.$ tet-a $\left.)\left(\mathrm{NO}_{2}\right)_{2}\right]$ & 8 & 8 \\
\hline$\left[\mathrm{Zn}\left(\right.\right.$ tet-b) $\left.\left(\mathrm{NO}_{2}\right)_{2}\right]$ & 10 & 11 \\
\hline$\left[\mathrm{ZnLI}_{2}\right]$ & 16 & 11 \\
\hline$\left[\right.$ Zn(tet-a) $\left.I_{2}\right]$ & 21 & 20 \\
\hline$\left[\mathrm{Zn}\left(\right.\right.$ tet-b) $\left.\mathrm{I}_{2}\right]$ & 4 & 4 \\
\hline$\left[\mathrm{ZnLBr}_{2}\right] \cdot 2 \mathrm{H}_{2} \mathrm{O}$ & 21 & 0 \\
\hline$\left[\mathrm{Zn}\right.$ (tet-a) $\left.\mathrm{Br}_{2}\right] \cdot 2 \mathrm{H}_{2} \mathrm{O}$ & 0 & 0 \\
\hline$\left[\mathrm{Zn}\right.$ (tet-b) $\left.\mathrm{Br}_{2}\right] \cdot 2 \mathrm{H}_{2} \mathrm{O}$ & 11 & 0 \\
\hline $\mathrm{Zn}\left(\mathrm{NO}_{3}\right)_{2} \cdot 6 \mathrm{H}_{2} \mathrm{O}$ & 4 & 3 \\
\hline Ampicillin (Standard) & 32 & 34 \\
\hline DMSO (Control) & 0 & 0 \\
\hline
\end{tabular}


Table 2: Antibacterial activities of the compounds against gram negative bacteria.

\begin{tabular}{|c|c|c|c|c|c|}
\hline \multirow{2}{*}{ Name of the compounds } & \multicolumn{5}{|c|}{ Inhibition zone of the compounds (mm) } \\
\hline & S. typhi & E. coli & S. sonnei & K. pneumonia & P. aeruginosa \\
\hline $\mathrm{L} .2 \mathrm{HClO}_{4}$ & 0 & 0 & 0 & 0 & 0 \\
\hline tet-a & 0 & 0 & 0 & 0 & 0 \\
\hline tet-b & 0 & 0 & 0 & 0 & 0 \\
\hline$\left[\mathrm{ZnL}(\mathrm{NCS})_{2}\right]$ & 15 & 12 & 8 & 10 & 17 \\
\hline$\left[\mathrm{Zn}(\right.$ tet-a $\left.)(\mathrm{NCS})_{2}\right]$ & 0 & 0 & 11 & 16 & 10 \\
\hline$\left[\mathrm{Zn}(\text { tet-b)(NCS })_{2}\right]$ & 0 & 9 & 8 & 6 & 7 \\
\hline$\left[\mathrm{ZnL}\left(\mathrm{NO}_{2}\right)\right]\left(\mathrm{ClO}_{4}\right)$ & 11 & 0 & 9 & 7 & 14 \\
\hline$\left[\mathrm{Zn}(\right.$ tet-a $\left.)\left(\mathrm{NO}_{2}\right)_{2}\right]$ & 12 & 14 & 12 & 16 & 10 \\
\hline$\left[\mathrm{Zn}\left(\right.\right.$ tet-b) $\left.\left(\mathrm{NO}_{2}\right)_{2}\right]$ & 0 & 0 & 10 & 8 & 0 \\
\hline$\left[\mathrm{ZnLI}_{2}\right]$ & 11 & 15 & 10 & 11 & 8 \\
\hline$\left[\mathrm{Zn}\left(\right.\right.$ tet-a) $\left.\mathrm{I}_{2}\right]$ & 10 & 16 & 0 & 0 & 11 \\
\hline$\left[\mathrm{Zn}\left(\right.\right.$ tet-b) $\left.\mathrm{I}_{2}\right]$ & 0 & 11 & 12 & 14 & 13 \\
\hline$\left[\mathrm{ZnLBr}_{2}\right] \cdot 2 \mathrm{H}_{2} \mathrm{O}$ & 15 & 12 & 10 & 10 & 9 \\
\hline$\left[\mathrm{Zn}\left(\right.\right.$ tet-a) $\left.\mathrm{Br}_{2}\right] \cdot 2 \mathrm{H}_{2} \mathrm{O}$ & 16 & 12 & 10 & 9 & 10 \\
\hline$\left[\mathrm{Zn}\left(\right.\right.$ tet-b) $\left.\mathrm{Br}_{2}\right] \cdot 2 \mathrm{H}_{2} \mathrm{O}$ & 0 & 0 & 18 & 21 & 20 \\
\hline $\mathrm{Zn}\left(\mathrm{NO}_{3}\right)_{2} \cdot 6 \mathrm{H}_{2} \mathrm{O}$ & 4 & 3 & 4 & 4 & 3 \\
\hline Ampicillin(Standard) & 25 & 28 & 30 & 31 & 27 \\
\hline DMSO (Control) & 0 & 0 & 0 & 0 & 0 \\
\hline
\end{tabular}

show activity against all gram negative bacteria.

Here though ligands are ineffective against both gram positive and gram negative bacteria but their metal complexes are effective, this phenomenon can be explained by the chelation theory [37]. Generally, the activity of the complexes are increased by the chelation. It can be assumed that, prohibition of the respiratory system and blocking the protein synthesis system to protect the growth of the bacteria by the complexes [38] can be responsible for antibacterial activity of the complexes.

\section{Conclusion}

This study reveals that the bimetallic nitrato complex $\left[(\mathrm{ZnL})_{2}\left(\mathrm{NO}_{3}\right]\left(\mathrm{ClO}_{4}\right)_{3}\right.$ of diene ligand $\mathrm{L}$, undergoes simultaneous axial addition and substitution reactions with $\mathrm{KSCN}_{2} \mathrm{KNO}_{2}, \mathrm{KI}$ and $\mathrm{KBr}$ to result monometallic axial addition and substitution products, $\left[\mathrm{ZnLX}_{\mathrm{m}}\left(\mathrm{ClO}_{4}\right)_{\mathrm{n}}\right] \cdot \mathrm{xH}_{2} \mathrm{O}\left(\mathrm{X}=\mathrm{NCS}, \mathrm{NO}_{2}\right.$, or $\mathrm{Br} ; \mathrm{m}=2$ or $1 ; \mathrm{n}=0$ or $1, \mathrm{x}=0$ or 2 ), whereas monometallic dinitrato complexes of tet-a and tet-b undergo only axial substitution reactions with the same reagents to produce monometallic axial substitution products, $\left[\mathrm{ZnL}^{*} \mathrm{X}_{2}\right] \cdot \mathrm{xH}_{2} \mathrm{O}$
$\left(\mathrm{L}^{*}=\right.$ tet-a or tet-b; $\mathrm{x}=0$ or 2 ). Regarding antibacterial activity, no complex was found to exhibit activity at a concentration below 2.5 $\mathrm{mg} / \mathrm{mL}$. The antibacterial activity was found to increase on coordination which can be explained by the chelation therapy.

\section{Acknowledgement}

We gratefully acknowledge the Research Cell, University of Chittagong, Bangladesh for awarding a Research Grant to Professor Dr. Debashis Palit and Professor Dr. Tapashi Ghosh Roy, Department of Chemistry, University of Chittagong, Bangladesh.

\section{Conflict of Interest}

There is no conflict of interest.

\section{Bibliography}

1. Fabbrizzi, L., et al. "A microcalorimetric determination of the enthalpies of formation in solution of nickel(II) complexes with tetraazamacrocyclic ligands of varying size". Inorganic Chemistry 19.2 (1980): 535-538. 
2. Singh D., et al. "Template synthesis and characterization of biologically active transition metal complexes comparing 14-membered tetraazamacrocyclic ligand". Journal of Serbian Chemical Society 75.2 (2010): 217-228.

3. Yao J., et al. "Synthesis, crystal structures and photoluminescent properties of the complexes of a new coumarin derivative with lanthanide ions". Inorganic Chemistry Communication 12.5 (2009): 430-432.

4. Suh MP., et al. "A redox-active two-dimensional coordination polymer: preparation of silver and gold nanoparticles and crystal dynamics on guest removal". Journal of American Chemical Society 128.14 (2006): 4710-4718.

5. Lippert B. "Cisplatin-chemistry and biochemistry of a leading anticancer drug”. WILEY-VCH<Weinheim (1999).

6. Hermann P., et al. "Gadolinium(III) complexes as MRI contrast agents: ligand design and properties of the complexes". Dalton Transaction 23 (2008): 3027-3047.

7. Ren YW., et al. "Carboxy ester hydrolysis promoted by two new bimetallic macrocyclic complexes. Synthesis, characterization and catalytic activity". Transition Metal Chemistry 31.5 (2006): 611-615.

8. Shankarwar SG., et al. "Synthesis, spectral, thermal and antimicrobial studies of transition metal complexes of 14-membered tetraaza[N4] macrocyclic ligand". Spectrochimca Acta Part A, 145 (2015): 188-193.

9. Pawar V., et al. "Synthesis, antioxidant and biocidal features of macrocyclic schiff bases with oxoanadium(V) complexes". Journal of Chemical and Pharmaceutical Research 3.1 (2011): 169-175.

10. Illan-Cabeza NA., et al. "Synthesis, characterization and antiproliferative activity of metal complexes with the Schiff base derived from the condensation 1:2 of 2,6-diformyl-4-methylphenol and 5,6-diamino-1,3-dimethyluracil". Journal of Inorganic Biochemistry 102.4 (2008): 647-655.

11. Vanco J., et al. "Synthesis, structural characterization, antiradical and antidiabetic activities of copper(II) and zinc(II) Schiff base complexes derived from salicylaldehyde and $\beta$-alanine". Journal of Inorganic Biochemistry 102.4 (2008): 595-605.

12. Galal SA., et al. "New transition metal ion complexes with benzimidazole-5-carboxylic acid hydrazides with antitumor activity". European Journal of Medicinal Chemistry 44.4 (2009): 1500-1508.
13. Chaviara AT., et al. "Copper(II) Schiff base coordination compounds of dien with heterocyclic aldehydes and 2-amino-5-methyl-thiazole: synthesis, characterization, antiproliferative and antibacterial studies. Crystal structure of CudienOOCl ${ }_{2}$. Journal of Inorganic Biochemistry 98.8 (2004): 1271-1283.

14. Shakir M., et al. "Synthesis, spectroscopic characterization, and in vitro antimicrobial screening of 16-membered tetraazamacrocyclic Schiff-base ligand and its complexes with $\mathrm{Co}(\mathrm{II}), \mathrm{Ni}(\mathrm{II}), \mathrm{Cu}(\mathrm{II})$, and $\mathrm{Zn}(\mathrm{II})$ ions". Synthesis and Reactivity in inorganic Metal organic and Nano-metal Chemistry 41 (2011): 979-986.

15. Yusoff SMA., et al. "Synthesis, characterization, and antibacterial activity of $\mathrm{Cu}(\mathrm{II}), \mathrm{Ni}(\mathrm{II})$ and $\mathrm{Zn}(\mathrm{II})$ complexes of 14-membered macrocyclictetraaza ligand". Oriental Journal of Chemistry 31.3 (2015): 1751-1758.

16. Benelli C., et al. "Electronic and CD spectra of catecholate and semiquinonate adducts of zinc(II) and nickel(II) tetraazamacrocyclic complexes". Inorganic Chemistry 28.8 (1989): 14761480 .

17. Hubin TJ., et al. "Synthesis, structure, and stability in acid of copper(II) and zinc(II) complexes of cross-bridged tetraazamacrocycles". Inorganica Chimica Acta 348 (2003): 33-40.

18. Yasmin S., et al. "Three transition-metal complexes with the macrocyclic ligand meso 5,7,7,12,14,14,-hexamethyl-1,4,8,11tetraazacyclotetradecane $(\mathrm{L}):\left[\mathrm{Cu}\left(\mathrm{ClO}_{4}\right)_{2}(\mathrm{~L})\right], \quad\left[\mathrm{Zn}\left(\mathrm{NO}_{3}\right)_{2}(\mathrm{~L})\right]$ and $\left[\mathrm{CuCl}(\mathrm{L})\left(\mathrm{H}_{2} \mathrm{O}\right)\right] \mathrm{Cl}$ ". Acta Crystallography C69 (2013): 862867.

19. Yasmin S., et al. "Synthesis, characterization and antimicrobial studies of zinc(II) complexes with hexamethyl-tetraazacyclotetradecadiene $\mathrm{Me}_{6}[14]$ diene (L) and C-chiral isomers of its reduced analogue". Journal of Inclusion Phenomena and Macrocyclic Chemistry 87 (2017): 239-250.

20. Barua S., et al. "Palladium complexes with hexamethyltetraazacyclotetradecadiene (L) and isomers of its reduced form ('tet-a' \& 'tet-b'): synthesis, characterization and antimicrobial studies". Journal of Inclusion Phenomena and Macrocyclic Chemistry 86 (2016): 291-303.

21. Biswas FB., et al. "An in vitro antibacterial and antifungal effects of cadmium(II) complexes of hexamethyltetraazacyclotetradecadiene ligands". Asian Pacific Journal Tropical Biomedicine 4 (2014): S618-S623. 
22. Curtis NF and Hay RW. "A novel heterocycle synthesis. Formation of 5,7,7,12,14,14-hexamethyl-1,4,8,11-tetra-azacyclotetradeca-4,11-diene dihydroperchlorate by reaction of diaminoethanemonohydroperchlorate with mesityl oxide or acetone". Chemical Communications (1966): 524-525.

23. Hay RW, et al. "A Convenient Synthesis of the Tetra-aza-macrocyclic Ligands trans-[14]-Diene, Tet a, and Tet b". Journal of Chemical Society Perkin Trans 1(1975): 591-593.

24. Roy TG., et al. "Axial ligand substitution in diastereoisomeric trans- $\left[\mathrm{Co}\left(\mathrm{Me}_{8}[14] \mathrm{ane}\right) \mathrm{Cl}_{2}\right]^{+}$Complexes and their anti-fungal activities". Journal of Coordination Chemistry 59(3) (2006): 351-362.

25. Hassu RL and Burmeister JL. "Solvent control of the bonding mode of co-ordinatedthiocyanate ion in cobalt(III) complexes". Chemical Communications (1971): 568.

26. Farago ME and James JM., "Coordination of Thiocyanate and Selenocyanate in Some Diamine Complexes of Nickel(II) and Copper(II)" Inorganic chemistry 4 (1965): 1706-1711.

27. Sabatini A and Bertin I "Infrared Spectra between 100 and $2500 \mathrm{Cm}^{-1}$ of Some Complex Metal Cyanates, Thiocyanates, and Selenocyanates". Inorganic chemistry 4 (1965): 959.

28. Roy TG., et al. "Synthesis, characterization and antifungal activities of some new copper(II) complexes of octamethyltetraazacyclotetradecadiene". Metal Based Drugs 6.6 (1999): 345-354.

29. Roy TG. "Synthesis, Characterisation and antimicrobial activities of some copper(II) and nickel(II) complexes of hexamethyltetraaza-cyclotetradecadiene, $\left.\mathrm{Me}_{6[} 14\right]$ diene and their substitution products". The Chittagong University Journal of Science 35 (2012): 122-142.

30. Bembi R., et al. "Polyazamacrocycles. 9. Characterization of diastereoisomeric trans- $\left(\mathrm{Co}\left(\mathrm{Me}_{8}[14] \mathrm{ane}\right) \mathrm{Cl}_{2}\right]^{+}$complexes". Inorganic Chemistry 30 (1991): 1403-1406.

31. Hay RW., et al. "Characterization of cis- $\left[\mathrm{CoCl}_{2} \mathrm{~L}\right]+$ and two diastereoisomeric trans- $\left[\mathrm{CoCl}_{2} \mathrm{~L}\right]+$ complexes and studies of the aquation kinetics (L=C-meso-5,12-dimethyl-1,4,8,11-tetraazacyclotetradecane)". Dalton Transaction (1984): 1921-1925.

32. Roy TG., et al. "trans(5,7, 7, 12, 14,14-Hexamethyl-1,4,8,11tetraazacyclotetradeca4,11-diene-қ4 $\quad \mathrm{N}, \quad \mathrm{N}^{\prime}, \mathrm{N}^{\prime \prime}, \mathrm{N}^{\prime \prime \prime}, \mathrm{N}^{\prime \prime \prime \prime}$ ) bis(nitrite-қN)-cobalt(III) perchlorate hemihydrates". Acta Crystallography E67 (2011): 1576-1577.
33. Greenwood NN., et al. "Behaviour of tellurium(IV) chloride, bromide, and iodide in organic solvents and the structures of the species present". Journal of Chemical Society A, (1968): 2209-2212.

34. Roy TG. "Axial addition in diastereoisomeric [Cu( $\mathrm{Me}_{8}[14]$ ane $\left.)\right]$ $\left.\left(\mathrm{ClO}_{4}\right)_{2}\right]$ complexes: anti-fungal and antibacterial activities". Journal of Coordination Chemistry 59 (2006) 1757-1767.

35. Roy TG., et al. "Copper(II) and nickel(II) complexes of N, Nbis(2-hydroxyethyl)-octamethyl-1,4,8,11-tetraaza-cyclotetradecan". European Journal of Inorganic Chemistry (2004): 41154123.

36. Roy TG., et al. "Synthesis, electrolytic behaviour and antimicrobial activities of cadmium Complexes of isomers of 3,10-Cmeso- 3,5,7,7,10,12,14,14-octamethyl-1,4,8,11-tetraazacyclotetradecane". Journal of Coordination Chemistry 40 (2007): 1567-1578.

37. Salehi M and Hasanzadeh M. "Characterization, crystal structures, electrochemical and antibacterial studies of four new binuclear cobalt(III) complexes derived from o-aminobenzyl alcohol". Inorganica Chimica Acta 426 (2015): 6-14.

38. Dharmaraj N., et al. "Ruthenium(II) complexes containing bidentate Schiff bases and their antifungal activity". Transition Metal Chemistry 26 (2001): 105-109.

\section{Assets from publication with us}

- Prompt Acknowledgement after receiving the article

- Thorough Double blinded peer review

- Rapid Publication

- Issue of Publication Certificate

- High visibility of your Published work

Website: www.actascientific.com/

Submit Article: www.actascientific.com/submission.php Email us: editor@actascientific.com

Contact us: +919182824667 